\title{
Enhancing genome investigations in the mosquito Culex quinquefasciatus via BAC library construction and characterization
}

\author{
Paul V Hickner ${ }^{1 \dagger}$, Becky deBruyn ${ }^{1 \dagger}$, Diane D Lovin ${ }^{1}$, Akio Mori ${ }^{1}$, Christopher A Saski ${ }^{2}$ and David W Severson ${ }^{1 *}$
}

\begin{abstract}
Background: Culex quinquefasciatus (Say) is a major species in the Culex pipiens complex and an important vector for several human pathogens including West Nile virus and parasitic filarial nematodes causing lymphatic filariasis. It is common throughout tropical and subtropical regions and is among the most geographically widespread mosquito species. Although the complete genome sequence is now available, additional genomic tools are needed to improve the sequence assembly.

Findings: We constructed a bacterial artificial chromosome (BAC) library using the plndigoBAC536 vector and HindIII partially digested DNA isolated from CX. quinquefasciatus pupae, Johannesburg strain (NDJ). Insert size was estimated by Notl digestion and pulsed-field gel electrophoresis of 82 randomly selected clones. To estimate genome coverage, each 384-well plate was pooled for screening with 29 simple sequence repeat (SSR) and five gene markers. The NDJ library consists of 55,296 clones arrayed in 144 384-well microplates. Fragment insert size ranged from 50 to $190 \mathrm{~kb}$ in length (mean $=106 \mathrm{~kb}$ ). Based on a mean insert size of $106 \mathrm{~kb}$ and a genome size of $579 \mathrm{Mbp}$, the BAC library provides $~ 10.1$-fold coverage of the $C$. quinquefasciatus genome. PCR screening of BAC DNA plate pools for SSR loci from the genetic linkage map and for four genes associated with reproductive diapause in Culex pipiens resulted in a mean of 9.0 positive plate pools per locus.
\end{abstract}

Conclusion: The NDJ library represents an excellent resource for genome assembly enhancement and characterization in Culex pipiens complex mosquitoes.

Keywords: Bacterial Artificial Chromosome, Culicidae, Culex pipiens/quinquefasciatus, Lymphatic filariasis, West Nile virus, Wuchereria bancrofti

\section{Introduction}

Culex quinquefasciatus (Say), the southern house mosquito, is a major vector for a number of important human pathogens including West Nile virus and Wuchereria bancrofti, the primary global etiologic agent for lymphatic filariasis (LF) [1-3]. It is estimated that more than 1.2 billion people are at risk for infection by parasites causing LF, with 120 million people presently infected [4]. Among these are over 40 million people who suffer from chronic morbidity associated with lymphadema and hydrocele [5]. Despite the availability of

\footnotetext{
* Correspondence: severson.1@nd.edu

† Contributed equally

'Eck Institute for Global Health, Department of Biological Sciences, University of Notre Dame, Notre Dame, IN 46556, USA

Full list of author information is available at the end of the article
}

effective antihelminthics to treat and prevent infections, the damage to the lymphatic system caused by these parasites is largely irreversible. Although efforts to eradicate LF globally using mass drug administration to human populations in endemic areas were initiated in 2000 , the success of these efforts will likely also rely on the implementation of effective mosquito vector control strategies [6]. However, vector control efforts can be hindered by the rapid selection for emergence of insecticide resistance [7]. Consequently, the identification of new targets for insecticides as well as the development of novel vector control strategies is expected to play a large role in the successful control and/or eradication of mosquito-borne diseases [8].

\section{Biomed Central}

() 2011 Severson et al; licensee BioMed Central Ltd. This is an open access article distributed under the terms of the Creative Commons Attribution License (http://creativecommons.org/licenses/by/2.0), which permits unrestricted use, distribution, and reproduction in any medium, provided the original work is properly cited. 
Cx. quinquefasciatus and Cx. pipiens (L.) are the two most common and geographically widespread species in the $C x$. pipiens complex, a species complex with nearly worldwide distribution [9]. Cx. quinquefasciatus is common in tropical and subtropical regions while $C x$. pipiens, the northern house mosquito, occupies more temperate regions. Both species are abundant in urban areas where they oviposit in stagnant, and often polluted water. They frequently enter homes and feed on humans during the night, hence the common name of house mosquito. The taxonomic status of this complex has been a subject of debate, and these taxa are sometimes placed within a single species, i.e., Cx. pipiens quinquefasciatus or $C x$. pipiens pipiens [9]. Introgression between these species is common in the United States where hybrids can be found as far south as Louisiana and as far north as Illinois [10-12], yet in South Africa the populations remain largely distinct $[13,14]$. Females are morphologically indistinguishable, while differences in male genitalia have been used to identify species as well as interspecies hybrids [10-12,15]. Recently, however, PCR assays have been developed to aid in the differentiation of species in this complex [16-19].

Given their medical importance, $C x$. pipiens complex mosquitoes have garnered considerable attention by the scientific community during the last 100 years [9]. Nevertheless, the current status of contemporary $C x$. pipiens genetics remains considerably behind that of other important mosquito vectors such as Anopheles gambiae and Aedes aegypti [20]. The Cx. quinquefasciatus (Johannesburg strain) genome sequence was recently determined using the whole genome shotgun (wgs) approach, thus providing a valuable resource for advancing genome studies in this species complex [21]. However, the genome assembly remains highly fragmented and few ( 40$)$ of the 3171 supercontigs have been assigned to their respective chromosomes [21].

Bacterial artificial chromosome (BAC) genomic libraries are important resources for the assembly and characterization of complex genomes. They have been utilized for the assembly of numerous genomes including Drosophila melanogaster and An. gambiae [22,23]. BAC libraries have also been used for the development of genetic markers for non-model organisms [24,25]. Furthermore, BAC clones can be used for positional cloning to help identify and characterize genomic regions of interest $[26,27]$, as well as for construction of BAC-based physical map assemblies [28-31]. These are useful for long-range contiguity and anchoring of wgs draft assemblies as well as targeted re-sequencing for high resolution using BAC pools [32]. The objective of this work was to construct a BAC library with comprehensive coverage of the $C x$. quinquefasciatus genome, thereby providing a tool to aid in genome assembly, marker development, and gene discovery in $C x$. pipiens complex mosquitoes.

\section{Methods \\ BAC library construction}

High molecular weight DNA was extracted from pupae from the Johannesburg (JHB) strain. This strain was established using individuals from Johannesburg South Africa, and was the strain used in the $C x$. quinquefasciatus genome project [21]. Pupae were gently homogenized in $1 \mathrm{X}$ PBS buffer containing $50 \mathrm{mM}$ EDTA pH 8.0 and $0.1 \%$ BME and filtered through one layer of miracloth into $50 \mathrm{~mL}$ Falcon tubes. Cells were pelleted by centrifugation in a swinging-bucket rotor (Beckman) at 3,200 rpm for 15 minutes at $4^{\circ} \mathrm{C}$. Pellets were washed 2 additional times with PBS and gently resuspended in 1 $\mathrm{mL}$ of PBS. The nuclei solution was warmed to $45^{\circ} \mathrm{C}$ in a waterbath, mixed gently with an equal volume of $1.5 \%$ low-melt agarose (Seaplaque) and aliquoted into plug molds (BioRad) using large-bore tips. Protein digestion and plug washing was performed exactly as the methods of Luo and Wing (2003) [33].

HindIII partial restriction enzyme digestion of DNA, as well as the preparation of high molecular weight DNA fragments was conducted following the procedure of Luo and Wing (2003) [33]. Preparation of the HindIII cloning-ready single copy pIndigoBAC536 vector from the high copy pCUGIBAC1 plasmid was performed according to Luo et al. (2001) [34]. The size selected high molecular fragments were ligated to the vector and transformed into E. coli strain DH10B competent cells (Invitrogen, Carlsbad, CA). White recombinant colonies were selected on LB plates containing chloramphenicol, X-Gal and IPTG, and picked robotically using the Genetix Q-bot (Genetix, UK). Recombinant clones were transferred into individual wells of microtiter plates, grown and then stored at $-80^{\circ} \mathrm{C}$. The BAC library was also gridded onto $10,11.25 \times 22.25 \mathrm{~cm}$ filters in high density, double spots $(18,432$ clones represented per filter) and $4 \times 4$ patterns.

To estimate the size of the BAC inserts, DNA from 82 randomly selected clones was prepared according to standard alkaline lysis protocol, digested with NotI, and separated by pulsed-field gel electrophoresis (PFGE) on a 1\% agarose gel under the following conditions: 5-15 sec linear ramp time, $6 \mathrm{~V} / \mathrm{cm}, 14^{\circ} \mathrm{C}$ in $0.5 \times \mathrm{TBE}$ buffer for 15 hours and stained with ethidium bromide. Insert sizes of the clones with endogenous Not I sites, evidenced by multiple restriction fragments, were estimated by summing the fragments. Southern blotting was used to confirm that all of the clones were truly $C x$. quinquefasciatus and are not significantly contaminated by other types of DNA. One gel used for insert size determination was transferred to a positively charged nylon 
Table 1 SSR primer sequences

\begin{tabular}{|c|c|c|c|c|}
\hline SSR locus & GenBank accession & SSR Primer Sequence (F/R) & Product size $(b p)^{a}$ & \# Positive plate pools \\
\hline \multirow[t]{2}{*}{ C127GAC1 } & GF102017 & GCGTTTGGAGAGTGGAAAAG & 307 & 10 \\
\hline & & TGAGTITTCAGTGCCCTCCT & & \\
\hline \multirow[t]{2}{*}{ C32AC1B } & GF110611 & AAACGATCGCAATTCGAAAC & 242 & 3 \\
\hline & & GTGGCGAACAACATTCACAG & & \\
\hline \multirow[t]{2}{*}{ C32TC1B } & GF110612 & TCATCGTTCATTCGTTCCAA & 179 & 2 \\
\hline & & TGTCATTITCTGCCTGCATC & & \\
\hline \multirow[t]{2}{*}{ C32TG1 } & GF102044 & CGTGTITCCATTGTTGGTG & 400 & 29 \\
\hline & & TTGGCTGTGTCAACTGCTTC & & \\
\hline \multirow[t]{2}{*}{ C68ACAT1 } & GF102032 & GGCCTTGCTGAGAAAACTTG & 425 & 1 \\
\hline & & CCCAAAATCCAAGCTTCAAA & & \\
\hline \multirow[t]{2}{*}{ C68CA1 } & GF102033 & ATAAAGCGACCAAGGCTCAA & 294 & 7 \\
\hline & & GCGAAACCATTCAAAAGCAT & & \\
\hline \multirow[t]{2}{*}{ C68GA1B } & GF110613 & CACCCCACAGTTAACCCAAC & 245 & 8 \\
\hline & & CTCGAGAGATTTGGCCTTTG & & \\
\hline \multirow[t]{2}{*}{$\mathrm{C} 65 \mathrm{AC} 1$} & GF102022 & GGAGTTGTGCGGTTGAAAGT & 305 & 19 \\
\hline & & GCACTGCCTAACGGATCATT & & \\
\hline \multirow[t]{2}{*}{ C65CGC1 } & GF102023 & TCTGGGTACAACCCCGTAAC & 221 & 20 \\
\hline & & AGAGAGTGCGCAAAAGCAAT & & \\
\hline \multirow[t]{2}{*}{ C65TG1 } & GF102021 & ACTGCGAAACGCTTACTGCT & 302 & 9 \\
\hline & & GTGTGTGGACTGTGGTGGAG & & \\
\hline \multirow[t]{2}{*}{ C474CT1B } & GF110614 & CCCAAACTTGCCACAAAAGT & 290 & 2 \\
\hline & & CTCACTCTCCGTGAACGACA & & \\
\hline \multirow[t]{2}{*}{ C48ATC1 } & GF102034 & CATTITCGGGTGGCTTCTA & 337 & 7 \\
\hline & & CGAGATCGAAATGATGCTGA & & \\
\hline \multirow[t]{2}{*}{ C48CGA1B } & GF110615 & GCTTGGGAATCTGAATCTGC & 251 & 4 \\
\hline & & ACCTTGCATTCAACGAGCTT & & \\
\hline \multirow[t]{2}{*}{ C48GTT1B } & GF110616 & GTGGCCACCTGGTTGTAGTT & 309 & 23 \\
\hline & & ACCACCGGTAGAACATCTCG & & \\
\hline \multirow[t]{2}{*}{ C175AT1 } & GF102036 & GGACCAAGGGTACGATTTGA & 185 & 14 \\
\hline & & CAGACTGGTTAACGGCTTCC & & \\
\hline \multirow[t]{2}{*}{ C175TG1 } & GF102045 & TCAGATCTCCGAGAGGAGGA & 295 & 4 \\
\hline & & CTGTCAGGGCCAGATTTCAT & & \\
\hline \multirow[t]{2}{*}{ C134AC1 } & GF102037 & GAAGGTCAGCCACTCAGGC & 194 & 0 \\
\hline & & ACAGCTGACTCTCGTCGAC & & \\
\hline \multirow[t]{2}{*}{ C129GT1 } & GF102038 & AAGGTGCAAAACCAAACTGG & 377 & 1 \\
\hline & & TGGAGCACAGCCCTACTCTT & & \\
\hline \multirow[t]{2}{*}{ C66CA1 } & GF102026 & CGACTACTGCCCCAATTTGT & 213 & 2 \\
\hline & & CACCCTCCCCTACAGACGTA & & \\
\hline \multirow[t]{2}{*}{ C177CA1B } & GF110618 & AGGGCAATGTITACGACGAC & 293 & 2 \\
\hline & & CTTGCGCCTTAGTCATCCTC & & \\
\hline \multirow[t]{2}{*}{ C177TG1 } & GF102028 & AGCACAAAAAGGCACGATTT & 197 & 6 \\
\hline & & TAAACGCAAGTAGGCGGAGT & & \\
\hline C99TGT1B & GF110619 & GCAGTGGAGGATTCTGAGGA & 358 & 5 \\
\hline & & CAGAACGTTTGGCGAATTIT & & \\
\hline C205CA1 & GF102029 & CAATGCGCCTTCTGGATTAT & 227 & 3 \\
\hline & & CTCGTGATGGCCATTTCTCT & & \\
\hline C205TG1B & GF110620 & ATTGCTCAAGTGCTGCCTIT & 212 & 7 \\
\hline & & ATGACGACGAAAAACCGAAC & & \\
\hline C139TG1B & GF110621 & GGGATCGCTACGTGTITGT & 265 & 6 \\
\hline & & TCTCGGAATGCCAGTCTITT & & \\
\hline C446AC2 & GF110622 & CATACGACGTGGAACAAACG & 162 & 17 \\
\hline
\end{tabular}


Table 1 SSR primer sequences (Continued)

\begin{tabular}{|c|c|c|c|c|}
\hline & & ACGAGGTTGAGGTTGGTGAC & & \\
\hline \multirow[t]{2}{*}{ C446TG1 } & GF102043 & GGAAAGGGGCACTTGTGTAA & 397 & 22 \\
\hline & & CGTTTGCTTCTCTTCGAACC & & \\
\hline \multirow[t]{2}{*}{ CxpGT4 } & AY423738 & GTCGTCGCTAACCCTTGTT & 146 & 2 \\
\hline & & CGCGATAGTCGGTAATCGT & & \\
\hline \multirow[t]{2}{*}{ CxqTri4 } & AY958079 & CTAGCCCGGTATTTACAAGAAC & 121 & 16 \\
\hline & & AACGCCAGTAGTCTCAGCAG & & \\
\hline
\end{tabular}

apredicted amplicon size based on nucleotide sequence in VectorBase [50].

Table 2 Primer sequences for genes used in library screening

\begin{tabular}{|c|c|c|c|c|c|}
\hline Gene & VectorBase gene ID & GenBank accession & SSR Primer Sequence (F/R) & Product size $(b p)^{a}$ & \# Positive plate pools \\
\hline \multirow[t]{2}{*}{$\mathrm{CHP*}^{*}$} & CPIJ007110 & GF110930 & CGAGCAGTTCAAACACCAGA & 207 & 12 \\
\hline & & & GCTTCTTCAGGTTGCTCCAC & & \\
\hline \multirow[t]{2}{*}{ FOXO } & CPIJ016794 & GF110931 & CTGAGCCCAATTCAGTCCAT & 187 & 3 \\
\hline & & & TCTGCTGTAAAGTCAGCTCGTC & & \\
\hline \multirow[t]{2}{*}{ ILP-1 } & CPIJ018051 & GF110932 & AGTCCCTCGGAGGAGTTCAA & 163 & 7 \\
\hline & & & TCGGCACAGTACTGCTTGAG & & \\
\hline \multirow[t]{2}{*}{ ILP-2 } & CPIJ018050 & GF110933 & TCCAGCAGATCTTCGATGC & 140 & 10 \\
\hline & & & TGTAGATCGGGGAACTCGTC & & \\
\hline \multirow[t]{2}{*}{ ILP-5 } & CPIJ001698 & GF110934 & GGTTCCATCACGCAGGAGT & 87 & 23 \\
\hline & & & GTTGATCCGCTTGTTCGAC & & \\
\hline
\end{tabular}

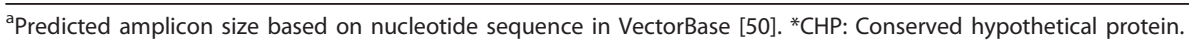

membrane Hybond $\mathrm{N}^{+}$(GE Healthcare) following the methods of Chomczynski (1992) [35]. BAC vector (pIndigoBAC536) and total Culex DNA were used as probes and radiolabeled with the DECAprime ${ }^{\mathrm{TM}}$ II kit (Ambion, Inc). The probes were mixed and denatured, and hybridization was carried out overnight at $60^{\circ} \mathrm{C}$. The membrane was washed with $1 \times \mathrm{SSC}, 0.1 \% \mathrm{SDS}$ at $60^{\circ} \mathrm{C}$ twice for one hour each. The membrane was exposed to a phosphor screen (GE Healthcare) overnight and the image recorded by a Typhoon 9400 imager (GE Healthcare).

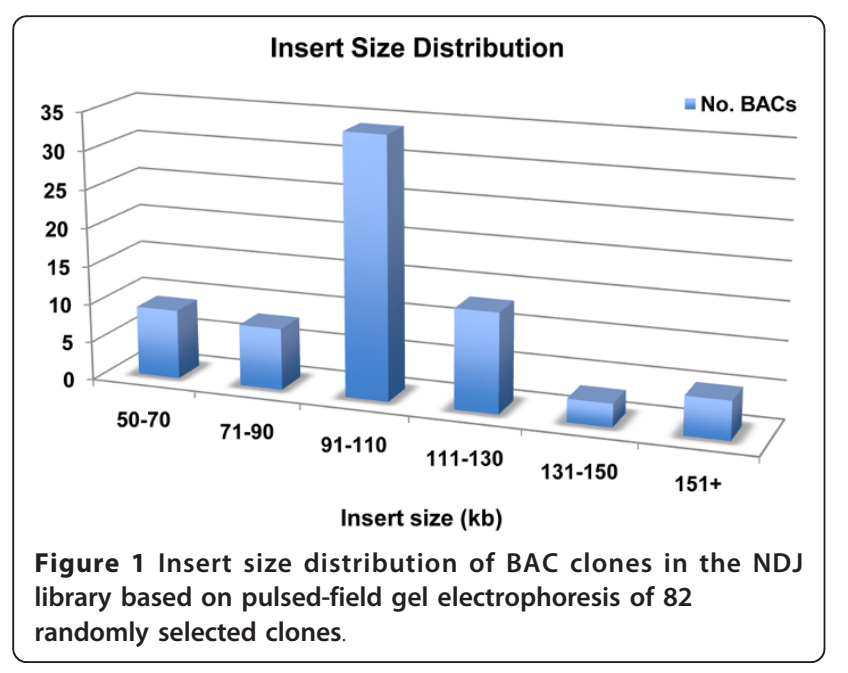

\section{BAC library screening}

Screening of the BAC library was generally performed as described by Jiménez et al. (2004) [36]. Briefly, we first prepared pools of DNA representing all clones within each of the individual 144 384-well microplates. Plates were initially replicated on LB agar plates containing $12.5 \mu \mathrm{g} / \mathrm{ml}$ chloramphenicol and incubated overnight at $37^{\circ} \mathrm{C}$. The plates were then flooded with LB broth containing $12.5 \mu \mathrm{g} / \mathrm{ml}$ chloramphenicol, agitated for $4 \mathrm{~h}$ at $37^{\circ} \mathrm{C}$ and the slurries used to prepare $9.5 \mathrm{ml}$ overnight cultures. These individual plate pool cultures were used for large-scale alkaline lysis DNA extractions [37] and subsequent PCR screening with SSR oligonucleotide primer sets.

A combination of PCR-based plate-pool DNA screening and radiolabeled oligonucleotide probe hybridization was used to screen the NDJ library. Initial PCR-based screening of BAC DNA representing individual plate pools was performed using 29 simple sequence repeats (SSRs) (Table 1) [38-40]. The Primer3 program [41] was used to design primers to amplify regions within a gene on supercontig 3.134 and four genes previously identified as having a role in reproductive diapause in $C x$. pipiens s.s. (Table 2) $[42,43]$. PCR reactions were performed in a total volume of $25 \mu \mathrm{l}$ containing $50 \mathrm{mM}$ $\mathrm{KCl}, 10 \mathrm{mM}$ Tris (pH 9.0), 0.1\% Triton X, $1.5 \mathrm{mM}$ $\mathrm{MgCl}_{2}, 200 \mu \mathrm{M}$ dNTPs, $5 \mathrm{pmol}$ of each primer ( $\mathrm{F}$ and R), $25 \mathrm{ng}$ of plate pool DNA and 1 unit of Taq 


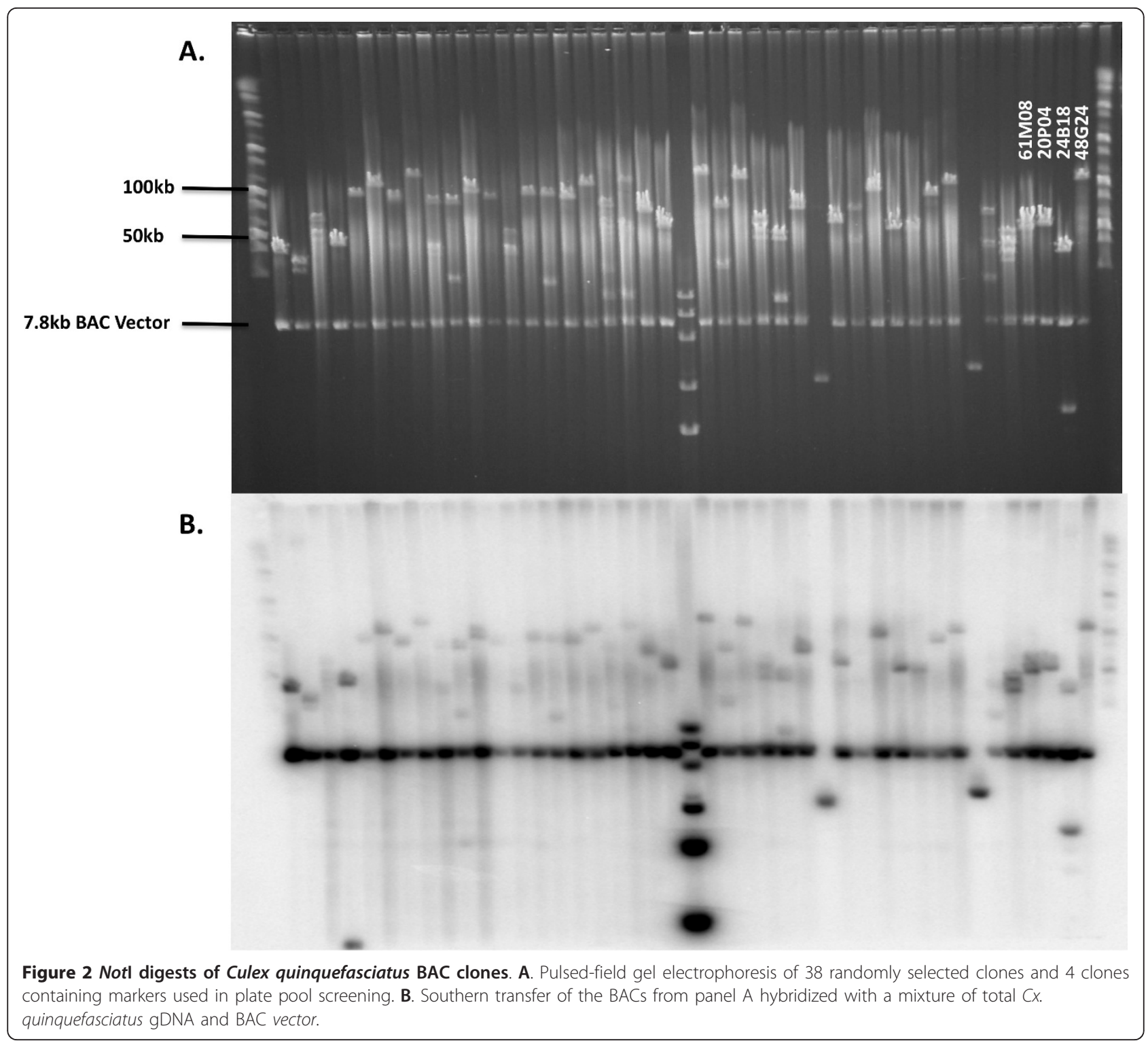

polymerase. PCR thermal cycling conditions were $5 \mathrm{~min}$. at $94^{\circ} \mathrm{C}$, followed by thirty cycles of $1 \mathrm{~min}$. at $94^{\circ} \mathrm{C}, 1$ min. at $60^{\circ} \mathrm{C}, 2 \mathrm{~min}$. at $72^{\circ} \mathrm{C}$, and then $10 \mathrm{~min}$. at $72^{\circ} \mathrm{C}$ for a final extension. The SSR positive plate pools were identified by electrophoresis on $2 \%$ agarose gels using ethidium bromide and UV visualization.

Well position of marker loci within select positive microplates was determined by DNA-DNA hybridization. Four individual clones were identified by probing with $\mathrm{P}^{32}$-labeled PCR amplicons (C127GAC1, C65AC1, C99TGT1, and FOXO) and thereafter sized with PFGE. Briefly, microplates representing positive pools were replicated to Colony/Plaque screen hybridization membranes (NEN ${ }^{\mathrm{TM}}$, Life Science Products) following Jiménez et al. [36]. Hybridizations and radiolabeling of the target clones were conducted following our standard probing procedures [44]. The presence of the marker locus in each of the four clones was confirmed by PCR and UV visualization on $2 \%$ agarose gels, as described for plate pool screening.

\section{Results and Discussion}

We have constructed a BAC library for Cx. quinquefasciatus, an important human disease vector and a major species in the $C x$. pipiens complex, using high molecular weight DNA extracted from Johannesburg strain pupae and partially digested with HindIII. The Notre Dame Johannesburg (NDJ) library consists of 144 384-well microplates containing 55,296 clones. NotI digestion and pulsed-field gel electrophoresis of 82 randomly selected 
clones produced fragments ranging from 50 to $190 \mathrm{~kb}$ in length (mean $=106 \mathrm{~kb}$ ) and no empty vectors (Figures 1 and 2). Southern blotting with BAC vector and $C x$. quinquefasciatus gDNA indicated that the inserts are of Culex origin and all BACs appear to be fully digested (Figure 2B). Based on a mean insert size of $106 \mathrm{~kb}$ and a genome size of $579 \mathrm{Mbp}$, the BAC library provides 10.1-fold coverage of the Cx. quinquefasciatus genome.

To further assess the quality of the library, we prepared and screened DNA extractions representing each of the 144 plate pools with 29 simple sequence repeat (SSR) markers representing all three linkage groups (Figure 3). The number of positive plate pools for each SSR ranged from 0 to 29 , resulting in a mean of 8.7 positive plate pools per screen. Only one of the SSR markers (C134AC1) did not amplify in any of the plate pools. Nevertheless, a gene sequence (CPIJ007110) on the same supercontig (3.134), $\sim 80 \mathrm{~kb}$ downstream, amplified in 12 plate pools. In addition to the SSRs, we screened the plate pools with primers designed to amplify sequences

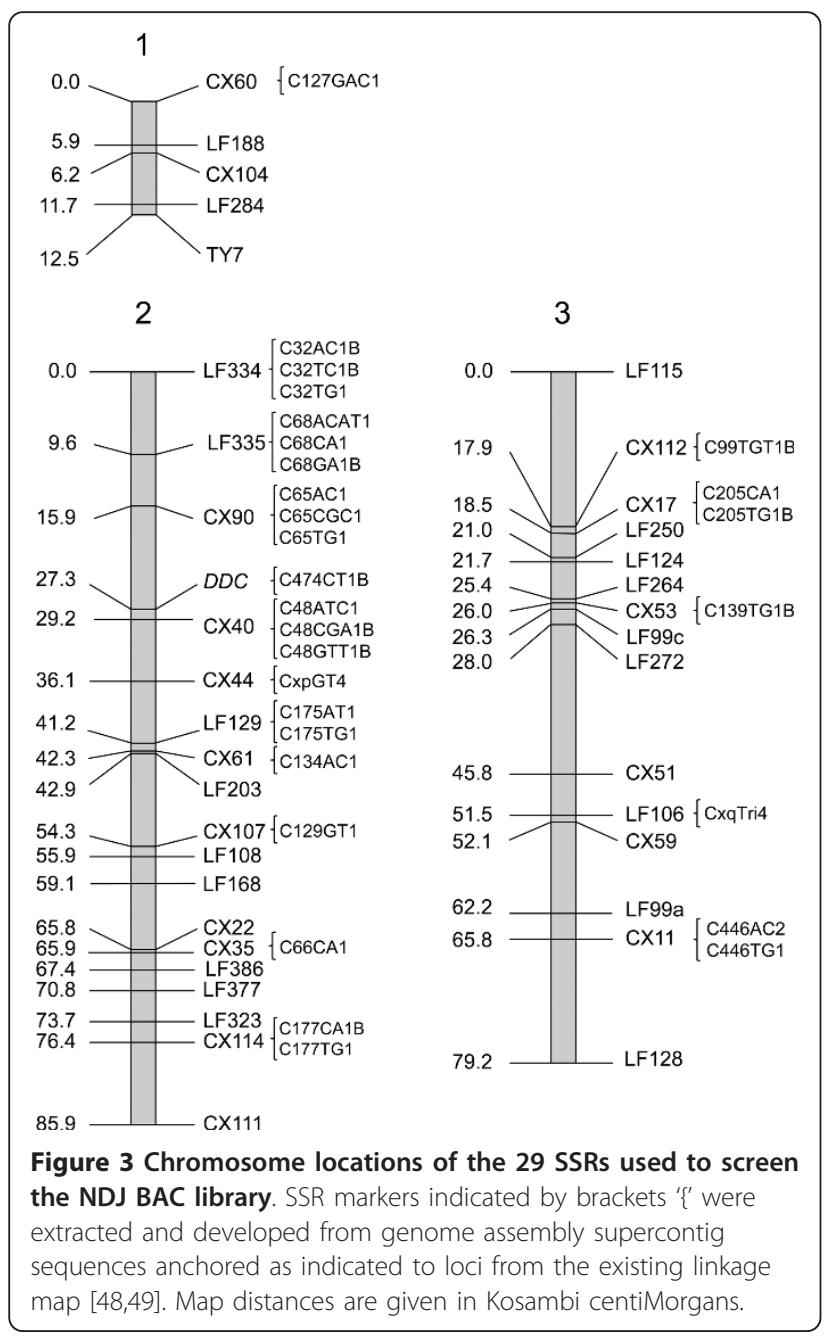

within exons of four genes previously determined to have a role in reproductive diapause in Cx. pipiens sensu stricto (s.s.) $[42,43]$. The number of positive plate pools for the gene sequences ranged from three to 23, resulting in a mean of 10.8 positive plate pools per gene (Table 2 ). The size distribution of the four individual clones selected by probing with radiolabeled markers is similar to the size distribution of the library (Figure 2A). The overall mean number of positive plate pools for the 29 SSRs and five genes used to screen the library was 9.0, indicating that the NDJ BAC library represents $\sim 9$ BAC clones per marker across the $C x$. quinquefasciatus genome, assuming that only one BAC clone per 384-well plate pool contains the target sequence.

Detailed genetic and genomic studies among the $C x$. pipiens complex could provide valuable insights into the molecular genetic mechanisms influencing important traits such as vector competence, insecticide resistance, and reproductive diapause. Despite morphological similarities and their ability to form hybrid populations, species within the complex differ in several life history traits. For example, Cx. quinquefasciatus requires a blood meal prior to laying eggs (anautogenous) and is unable to enter diapause and overwinter in cold climates. $C x$. pipiens and $C x$. pipiens pallens also are anautogenous but adult females are able to enter reproductive diapause and survive winter in temperate climates, and Cx. pipiens molestus is able to lay eggs without taking a blood meal (autogenous) but does not enter diapause [45-47]. Presently, detailed molecular analyses of these traits are limited by the fragmented genome assembly. Fingerprinting, end-sequencing and physical assembly of the NDJ BAC library would likely facilitate the construction of a more complete genome sequence assembly by serving as a template for genome finishing, including gap-filling, as well as providing resources to enable the assignment of the individual superscaffolds to their respective chromosome position via in situ hybridization. In summary, the NDJ BAC library provides a valuable resource for marker development, positional cloning, and genome sequence assembly enhancement for $C x$. quinquefasciatus thus helping to advance genome studies in $C x$. pipiens complex mosquitoes.

\section{Library availability}

The NDJ BAC library is available to researchers through the Clemson University Genomics Institute (see Culex pipiens library CPQLBa at http://www.genome.clemson. $\mathrm{edu} /)$.

\section{Acknowledgements}

This work was supported by grant RO1-Al079125 from the National Institute of Allergy and Infectious Diseases, National Institutes of Health, USA. 


\section{Author details}

${ }^{1}$ Eck Institute for Global Health, Department of Biological Sciences, University of Notre Dame, Notre Dame, IN 46556, USA. ${ }^{2}$ Clemson University Genomics Institute, Clemson, SC 29634, USA.

\section{Authors' contributions}

PVH drafted the manuscript and helped design probes for library screening AM performed the initial genetic mapping and provided the pupae used in library construction. CAS constructed the library, estimated insert sizes and assisted in writing the manuscript. BD and DDL designed probes for library screening. BD performed plate pool screening. The project was conceived and supervised by DWS. All authors approved of the final version.

\section{Competing interests}

The authors declare that they have no competing interests.

Received: 21 April 2011 Accepted: 13 September 2011

Published: 13 September 2011

\section{References}

1. Turell MJ, O'Guinn ML, Dohm DJ, Jones JW: Vector competence of North American mosquitoes (Diptera: Culicidae) for West Nile virus. J Med Ent 2001, 38:130-134.

2. Fonseca DM, Keyghobadi N, Malcolm CA, Mehmet C, Schaffner F, Mogi M, Fleischer RC, Wilkerson RC: Emerging vectors in the Culex pipiens complex. Science 2004, 303:1535-1538.

3. Michalski ML, Erickson SM, Bartholomay LC, Christensen BM: Midgut barrier imparts selective resistance to filarial worm infection in Culex pipiens pipiens. PLoS Negl Trop Dis 2010, 4:e875.

4. Michael E, Bundy DA, Grenfell BT: Reassessing the global prevalence and distribution of lymphatic filariasis. Parasitology 1996, 112:409-428.

5. Addiss DG, Brady MA: Morbidity management in the global programme to eliminate lymphatic filariasis: a review of the scientific literature. Filaria J 2007, 6:2-20

6. Bockarie MJ, Pedersen EM, White GB, Michael E: Role of vector control in the global program to eliminate lymphatic filariasis. Annu Rev Entomol 2009, 54:469-487.

7. Hemingway J, Ranson $\mathrm{H}$ : Insecticide resistance in insect vectors of human disease. Annu Rev Entomol 2000, 45:371-391.

8. Hill CA, Kafatos FC, Stansfield SK, Collins FH: Arthropod-borne diseases: vector control in the genomics era. Nature Rev Microbiol 2005, 3:262-268.

9. Vinogradova EB: Culex pipiens pipiens mosquitoes: taxonomy, distribution, ecology, physiology, genetics, applied importance and control Sofia: Pensoft; 2000.

10. Barr AR: The distribution of Culex p. pipiens and Culex p. quiquefasciatus in North America. Am J Trop Med Hyg 1957, 6:153-165.

11. Cheng ML, Hacker CS, Pryor SC, Ferrell RE, Kitto GB: The ecological genetics of the Culex pipiens complex in North America. In Recent Developments in The Genetics of Insect Disease Vectors. Edited by: Steiner WWM, Tabachnick WJ, Rai S, Narang KS. Champaign: Stipes; 1982:581-627.

12. Kothera L, Zimmerman EM, Richards CM, Savage HM: Microsatellite characterization of subspecies and their hybrids in Culex pipiens complex (Diptera: Culicidae) mosquitoes along a north-south transect in the central United States. J Med Ent 2009, 46:236-248.

13. Jupp PG: Culex (Culex) pipiens pipiens Linnaeus and Culex (Culex) pipiens quinquefasciatus Say in South Africa: morphological and reproductive evidence in favour of their status as two species. Mosa Systematics 1978 10:461-473.

14. Cornel AJ, McAbee RD, Rasgon J, Stanich MA, Scott TW, Coetzee M: Differences in extent of genetic introgression between sympatric Culex pipiens and Culex quinquefasciatus (Diptera: Culicidae) in California and South Africa. J Med Entomol 2003, 40:36-51.

15. Sundararaman S: Biometrical studies on intergradation in the genitalia of certain populations of Culex pipiens and Culex quinquefasciatus in the United States. Am J Hyg 1949, 50:307-314.

16. Crabtree MB, Savage HM, Miller BR: Development of a species-diagnostic polymerase chain reaction assay for the identification of Culex vectors of St. Louis Encephalitis virus based on interspecies sequence variation in ribosomal DNA spacers. Am J Trop Med Hyg 1995, 53:105-109.

17. Bourguet D, Fonseca D, Vourch G, Dubois M-P, Chandre F, Severini C, Raymond M: The acetylcholinesterace gene Ace: a diagnostic marker for the quinquefasciatus and pipiens forms of the Culex pipiens complex. J Am Mosq Control Assoc 1998, 14:390-396.

18. Aspen S, Savage H: Polymerase chain reaction assay identifies North American members of the Culex pipiens complex based on nucleotide sequence differences in the acetylcholinesterase gene Ace.2. J Am Mosa Cont Assoc 2003, 19:323-328.

19. Smith JL, Fonseca DM: Rapid assays for identification of members of the Culex (Culex) pipiens complex, their hybrids, and other sibling species (Diptera: Culicidae). Am J Trop Med Hyg 2004, 70:339-345.

20. Severson DW, Brown SE, Knudson DL: Genetic and physical mapping in mosquitoes: molecular approaches. Annu Rev Entomol 2001, 46:183-219.

21. Arensburger P, Megy K, Waterhouse RM, Abrudan J, Amedeo P, Antelo B, Bartholomay L, Bidwell S, Caler E, Camara F, Campbell CL, Campbell KS, Casola C, Castro MT, Chandramouliswaran I, Chapman SB, Christley S, Costas J, Eisenstadt E, Feschotte C, Fraser-Liggett C, Guigo R, Haas B, Hammond M, Hansson BS, Hemingway J, Hill SR, Howarth C, Ignell R, Kennedy RC, et al: Sequencing of Culex quinquefasciatus establishes a platform for mosquito comparative genomics. Science 2010, 330:86-88

22. Adams MD, Celniker SE, Holt RA, Evans CA, Gocayne JD, Amanatides PG, Scherer SE, Li PW, Hoskins RA, Galle RF, George RA, Lewis SE, Richards S, Ashburner M, Henderson SN, Sutton GG, Wortman JR, Yandell MD, Zhang Q, Chen LX, Brandon RC, Rogers YHC, Blazej RG, Champe M, Pfeiffer BD, Wan KH, Doyle C, Baxter EG, Helt G, Nelson CR, Beasley EM, Berman BP, Bolshakov S, Borkova D, Botchan MR, Bouck J, Brokstein P, Brottier P, Burtis KC, Busam DA, Butler H, Cadieu E, Center A, Chandra I, Cherry JM, Cawley S, Dahlke C, Davenport LB, Davies A, de Pablos B, Delcher A, Deng ZM, Mays AD, Dew I, Dietz SM, Dodson K, Doup LE, Downes M, Dugan-Rocha S, Dunkov BC, Dunn P, Durbin K, Evangelista CC, Ferraz C, Ferriera S, Fleischmann W, Fosler C, Gabrielian AE, Garg NS, Gelbart WM, Glasser K, Glodek A, Gong FC, Gorrell JH, Gu ZP, Guan P, Harris M, Harris NL, Harvey D, Heiman TJ, Hernandez JR, Houck J, Hostin D, Houston DA, Howland TJ, Wei MH, Ibegwam C, Jalali M, Kalush F Karpen GH, Ke ZX, Kennison JA, Ketchum KA, Kimmel BE, Kodira CD, Kraft C, Kravitz S, Kulp D, Lai ZW, Lasko P, Lei YD, Levitsky AA, Li JY, Li ZY, Liang Y, Lin XY, Liu XJ, Mattei B, Mclntosh TC, McLeod MP, McPherson D, Merkulov G, Milshina NV, Mobarry C, Morris J, Moshrefi A, Mount SM, Moy M, Murphy B, Murphy L, Muzny DM, Nelson DL, et al: The genome sequence of Drosophila melanogaster. Science 2000, 287:2185-2195.

23. Holt RA, Subramanian GM, Halpern A, Sutton GG, Charlab R, Nusskern DR, Wincker P, Clark AG, Ribeiro JMC, Wides R, Salzberg SL, Loftus B, Yandell M, Majoros WH, Rusch DB, Lai ZW, Kraft CL, Abril JF, Anthouard V, Arensburger P, Atkinson PW, Baden $H$, de Berardinis V, Baldwin D, Benes V, Biedler J, Blass C, Bolanos R, Boscus D, Barnstead M, et al: The genome sequence of the malaria mosquito Anopheles gambiae. Science 2002, 298:129-149.

24. Temnykh S, DeClerck G, Lukashova A, Lipovich L, Cartinhour S, McCouch S: Computational and experimental analysis of microsatellites in rice (Oryza sativa L.): frequency, length variation, transposon associations, and genetic marker potential. Genome Res 2001, 11:1441-1452.

25. Ellison CK, Shaw KL: Mining non-model genomic libraries for microsatellites: BAC versus EST libraries and the generation of allelic richness. BMC Genomics 2010, 11:e428.

26. Perelygin AA, Scherbik SV, Zhulin IB, Stockman BM, Li Y, Brinton MA Positional cloning of the murine flavivirus resistance gene. Proc Natl Acad Sci USA 2002, 99:9322-9327.

27. Luo M, Yu Y, Kim H-R, Kudrna D, Itoh Y, Agate RJ, Melamed E, Goicoechea JL, Talag J, Mueller C, Wang W, Currie J, Sisneros NB, RA W, Arnold AP: Utilization of a zebra finch BAC library to determine the structure of an avian androgen receptor genomic region. Genomics 2006, 87:181-190.

28. Quiniou SM-A, Waldbieser GC, Duke MV: A first generation BAC-based physical map of the channel catfish genome. BMC Genomics 2007, 8:e40.

29. Palti Y, Luo MC, Hu Y, Genet C, You FM, Vallejo RL, Thorgaard GH, Wheeler PA, Rexroad CE III: A first generation BAC-based physical map of the rainbow trout genome. BMC Genomics 2009, 10:e462.

30. Fang G-C, Blackmon BP, Henry DC, Staton ME, Saski CA, Hodges SA, Tomkins JP, Luo H: Genomic tools development for Aquilegia: construction of a BAC-based physical map. BMC Genomics 2010, 11:e621.

31. Xia JH, Feng F, Lin G, Wang CM, Yue GH: A first generation BAC-based physical map of the Asian seabass (Lates calcarifer). PLoS One 2010, 5 : e11974 
32. Rounsley S, Marri PR, Yu Y, He R, Sisneros N, Goicoechea JL, et al: De novo next generation sequencing of plant genomes. Rice 2009, 2:35-43.

33. Luo M, Wing RA: An improved method for plant BAC library construction. In Plant Functional Genomics. Edited by: Grotewold E. Totowa: Humana; 2003:3-19.

34. Luo M, Wang YH, Frisch D, Joobeur T, Wing RA, Dean RA: Melon bacterial artificial chromosome (BAC) library construction using improved methods and identification of clones linked to the locus conferring resistance to melon Fusarium wilt (Fom-2). Genome 2001, 44:154-162.

35. Chomczynski P: One-hour downward alkaline capillary transfer for blotting of DNA and RNA. Anal Biochem 1992, 201:134-139.

36. Jiménez LV, Kang B, deBruyn B, Lovin DD, Severson DW: Characterization of an Aedes aegypti bacterial artificial chromosome (BAC) library and chromosomal assignment of BAC clones for physical mapping quantitative trait loci that influence Plasmodium susceptibility. Insect Mol Biol 2004, 13:37-44

37. Birnboim HC, Doly J: A rapid alkaline extraction procedure for screening recombinant plasmid DNA. Nucleic Acids Res 1979, 7:1513-1523.

38. Keyghobadi N, Matrone MA, Ebel GD, Kramer LD, Fonseca DM: Microsatellite loci from the northern house mosquito (Culex pipiens), a principal vector of West Nile virus in North America. Mol Ecol Notes 2004, 4:20-22.

39. Smith JL, Keyghobadi N, Matrone MA, Escher RL, Fonseca DM: Crossspecies comparison of microsatellite loci in the Culex pipiens complex and beyond. Mol Ecol Notes 2005, 5:697-700.

40. Hickner PV, deBruyn B, Lovin DD, Mori A, Behura SK, Pinger R, Severson DW: Genome-based microsatellite development in the Culex pipiens complex and comparative microsatellite frequency with Aedes aegypti and Anopheles gambiae. PLoS One 2010, 5:e13062.

41. Rozen S, Skaletsky HJ: Primer3 on the WWW for general users and for biologist programmers. In Bioinformatics Methods and Protocols: Methods in Molecular Biology. Edited by: Krawetz S, Misener S. Totowa: Humana; 2000:365-386.

42. Sim C, Denlinger DL: Insulin signaling and FOXO regulate the overwintering diapause of the mosquito Culex pipiens. Proc Natl Acad Sci USA 2008, 105:6777-6781.

43. $\operatorname{sim} C$, Denlinger $D L$ : A shut-down in expression of an insulin-like peptide, ILP-1, halts ovarian maturation during the overwintering diapause of the mosquito Culex pipiens. Insect Mol Biol 2009, 18:325-332.

44. Severson DW: RFLP analysis of insect genomes. In The Molecular Biology of Insect Disease Vectors: a Methods Manual. Edited by: Crampton JM, Beard CB, Louis C. London: Chapman and Hall; 1997:309-320.

45. Tekle A: The physiology of hibernation and its role in the geographical distribution of populations of the Culex pipiens complex. Am J Trop Med Hyg 1960, 9:321-330.

46. Eldridge BF: Environmental control of ovarian development in mosquitoes of the Culex pipiens complex. Science 1966, 151:826-828.

47. Eldridge BF: The effect of temperature and photoperiod on bloodfeeding and ovarian development in mosquitoes of the Culex pipiens complex. Am J Trop Med Hyg 1968, 17:133-140.

48. Mori A, Severson DW, Christensen BM: Comparative linkage maps for the mosquitoes (Culex pipiens and Aedes aegypti) based on common RFLP loci. J Hered 1999, 90:160-164.

49. Mori A, Romero-Severson J, Severson DW: Genetic basis for reproductive diapause is correlated with life history traits within the Culex pipiens complex. Insect Mol Biol 2007, 16:515-524.

50. Lawson D, Arensburger P, Atkinson P, Besansky NJ, Bruggner RV, Butler R, Campbell KS, Christophides GK, Christley S, Dialynas E, Emmert D Hammond M, Hill CA, Kennedy RC, Lobo NF, MacCallum MR, Madey G, Megy K, Redmond S, Russo S, Severson DW, Stinson EO, Topalis P, Zdobnov EM, Birney E, Gelbart WM, Kafatos FC, Louis C, Collins FH: VectorBase: a data resource for invertebrate vector genomics. Nucleic Acids Res 2009, 37:583-587.

doi:10.1186/1756-0500-4-358

Cite this article as: Hickner et al.: Enhancing genome investigations in the mosquito Culex quinquefasciatus via BAC library construction and characterization. BMC Research Notes 2011 4:358. 